\title{
Presentation of Gudrun D. Whitehead
}

Dr Gudrun D. Whitehead is an Assistant Professor in Museum Studies at the University of Iceland. She has worked there in various roles, since being awarded a Ph.D. in Museum Studies from the University of Leicester. She has taught a variety of courses, including Trash Cultures, Museum Education, Museum Studies Theories and Professional Occupations in Museums. She is also involved in developing distance learning teaching methods in the Museum Studies programme at her university. Currently, she is the deputy (assistant) head of the Folklore and Museum Studies programme, as well as being a deputy member of the University of Iceland's research ethics review committee. Whitehead is also the project manager in the University of Iceland and National Museum of Iceland's collaborative committee.

Whitehead's background in literary and folklore studies has had an impact on her research interests. She has focused on subculture, the uncanny and disruptive elements of society, such as Vikings, horror, punk and unconventional museum displays. She is particularly interested in cultural stereotypes, such as Vikings and their uses in the heritage industry and society in general. During her Ph.D. studies, Whitehead researched the image of Vikings in Icelandic and English society and museums in relation to visitor and staff responses to Viking related exhibitions. In other words, Viking identity is performed in museums, catering for foreign and domestic visitor markets. This allows the past (academic history) and present (public history) to merge in a unified narrative. Currently, she is developing this research further, extending it to Norway and focusing more thoroughly on Viking exhibitions as a platform for negotiating heritage in a way that suits the needs of both an external and internal audience. This will demonstrate the inherent tension between the two in relation to tourism and heritage marketing.

Along with Dr Julia Petrov, Whitehead is co-editing a volume, Fashioning Horror. Dressing to Kill on Screen and in Literature, which is being published with Bloomsbury in December 2017. Their introductory chapter introduces the horrors of fashion and the fashion of horror through the ages, focusing particularly on the use of horror in daily life and marketing strategies. Whitehead has also been involved in several other editing projects, including being a member of the board of editors and a contributor to Safnablaðið Kvistur (2014-2016), the Icelandic museums magazine. In 2015, she co-edited (with Sólrún Traustadóttir) a special issue of Ólafía, the Icelandic archaeological society's official journal, titled: Tími, rými og sýnileiki [Time, Space and Visibility]. She is the leading editor of a forthcoming special edition of Museum \& Society, A Child's Eye View of Museums. Remembering Elee Kirk, which will be published in 2018. Other forthcoming publications include "We come from the land of the ice and snow. Icelandic heritage and its usage in present day society", a book 


\section{Presentation av Gudrun D. Whitehead}

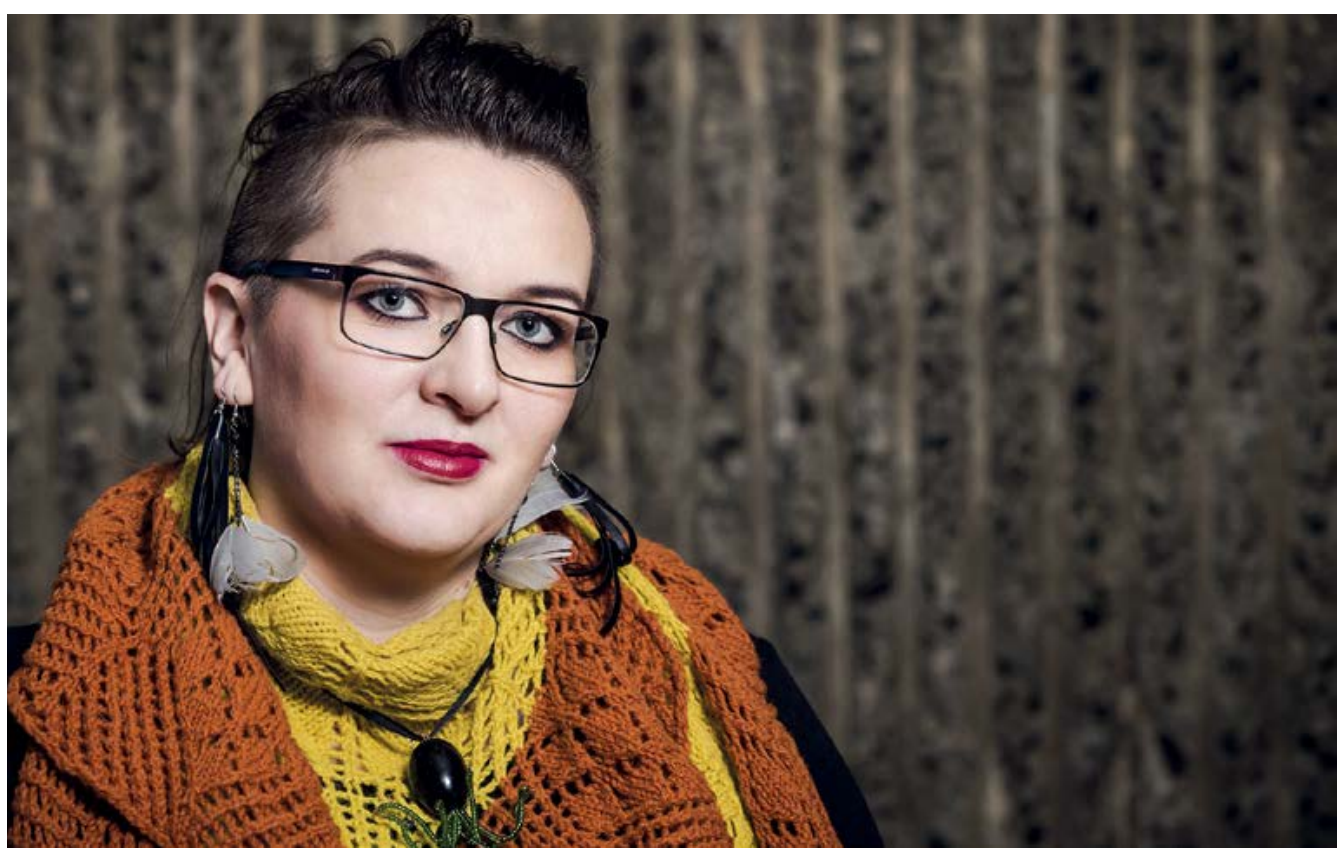

Fig. 1. Gudrun D. Whitehead. Photo: Kristinn Ingvarsson, University of Iceland.

chapter included in the Heritage Reader in the Leicester Museum Studies Series, to be published by Routledge in 2017.

Whitehead is also currently concluding research on the Saga Museum, Reykjavík, Iceland, where she explores the visual representation of Iceland's literary past, using multifarious storytelling devices, including theatrical techniques, auditory and textual elements and macabre realism. The museum is shown to represent locally important (hi) stories, rooted at the core of the local, national character and external tourism character traits. Other research projects include subversive exhibition methods at the Icelandic Punk Museum, ethical considerations regarding human remains in museums in Iceland (along with Joe Wallace Walser III), the display of horror in museums, and more. A range of topics, relating to the representation and uses of cultural heritage in Icelandic museums, have also been thematised in her contributions to recent conferences as the SIEF 2017 congress in Gottingen, Germany, the Uartic 2017 conference, University of Aberdeen, Scotland, and the ICOM Germany and ICOM Nord 2017 conference in Helsingborg, Sweden.
Dr Gudrun D. Whitehead
gdw@hi.is

University of Iceland

Somundargata 2

IS-101 Reykjavík, Iceland 